\title{
Characteristics of 137 macaw palm (Acrocomia aculeata) fruit accessions from Goias, Brazil
}

\author{
Edésio Fialho dos Reis, Jefferson Fernando Naves Pinto, Hildeu Ferreira da Assunção, \\ Antonio Paulino da Costa Netto, Danielle Fabiola Pereira da Silva*
}

Federal University of Goias, Jataí, Brazil

*Corresponding author, e-mail: daniellefpsilva@gmail.com

\begin{abstract}
Accessions of macaw palm fruits from the State of Goias, Brazil were characterized aiming the identification of groups with similar characteristics and indicate groups with higher agronomic potential, using multivariate tools. Fruit were harvested with completed yellow fruit bunches without whitish scores. The evaluated variables were fruit and almond length, fruit and almond diameters, fruit and dehydrated almond weight, average number of almonds, oil percentage of almond and dried fruit. The genetic diversity of populations was evaluated by Ward's clustering method and Person's correlation was obtained to evaluate the relative importance of each characteristic and variance analysis associated with Tukey's test to verify the group's effects. The studied population demonstrated great variability. The characteristics that most contributed to the variability were fruit weight and diameter and the almond's oil percentage. Ward's group analysis revealed six groups of similarity, being significant for all evaluated characteristics. Group VI stood out for all evaluated characteristics and group III presented the best averages for the almond's weight and almonds and dried fruit oil percentage.
\end{abstract}

Keywords: Divergence, almond quality, agroenergy, biodiesel, oleaginous seed

\section{Introduction}

The macaw palm [Acrocomia aculeata

(Jaca.) Lodd. ex Mart.] is a naturally occurring palm tree in almost all Brazilian territory (Pimentel et al., 2015). Due to the plant high yield and seeds with high oil content, this species presents great potential for agricultural exploitation. The oil from the mesocarp contains high amounts of oleic acid, which presents great demand in the food industry and especially in the agroenergy industries, due to the biodiesel production (Coimbra \& Jorge, 2011). Macaw palm is mainly cultivated by small growers, which is considered of great socioeconomic importance (Oliveira et al., 2016). However, this species has been exploited in an extractive way and in populations with heterogeneous plants, which makes difficult the application of management techniques, leading to low fruit yield and quality.

The Macaw palm is in the process of domestication (Domiciano et al., 2015), and studies aiming the genetic improvement of this species have been carried out in Brazilian research centers. To evaluate the potential yield of different genotypes, quantitative, qualitative and chemical analyzes of its fruits (Matsimbe et al., 2015) were carried out.

Thus, the identification of macaw palm accessions that present better agronomic characteristics constitutes an important step in 
the improvement of the species cultivation.

According to Faria Neto et al. (2013) the success of a breeding program is directly related to the genotypes choice. The selection of the genotypes that present the maximum variability depends on the choice of the grouping methods, which according to Bertan et al. (2006), is directly related to the researcher's sensitivity, being influenced by the desired precision, analysis resources and how the data were obtained (Chagas et al., 2016).

Within this reality, numerous studies are carried out with fruit characterization and using multivariate techniques to evaluate the genetic diversity, in order to allow more efficient breeding programs, reducing the time to obtain promising materials with lower costs (Silva et al., 2016).

Studies on the characterization and genetic diversity of macaw palm fruits in the state of Goiás, Brazil, are still incipient. Thus, the present study aim to evaluate the genetic diversity through the fruit characterization of 137 macaw palm accessions from Goias, Brazil, in order to determine groups of accessions with similar characteristics; to indicate groups of accessions with greater agronomic potential and to identify the accessions that should compose a breeding program.

\section{Material and Methods}

Fruits from 137 macaw palm trees were harvested from January to February, 2011. The fruits were obtained from palms existing in 35 municipalities in the state of Goiás (Acreúna, Araucapaz, Cachoeira Dourada, Caçu, Campos Belos, Divinópolis de Goiás, Edéia, Faina, Firminópolis, Formosa, Goiânia, Goiás, Inaciolândia, Indiara, Iporá, Itaberai, Itarumã, Itumbiara, Jataí, Montividiu do Norte, Nova Crixás, Palmeiras de Goiás, Palminópolis, Paranã, Posse, Pontalina, Porangatu, Santa Helena, São Domingos, São João da Paraúna, São Luís de Montes Belos, Serranópolis, and Turvânia) (Figure 1). Several expeditions were made to these municipalities and the bunches were always collected in morning periods. Four macaw palm clusters were collected in each municipality.

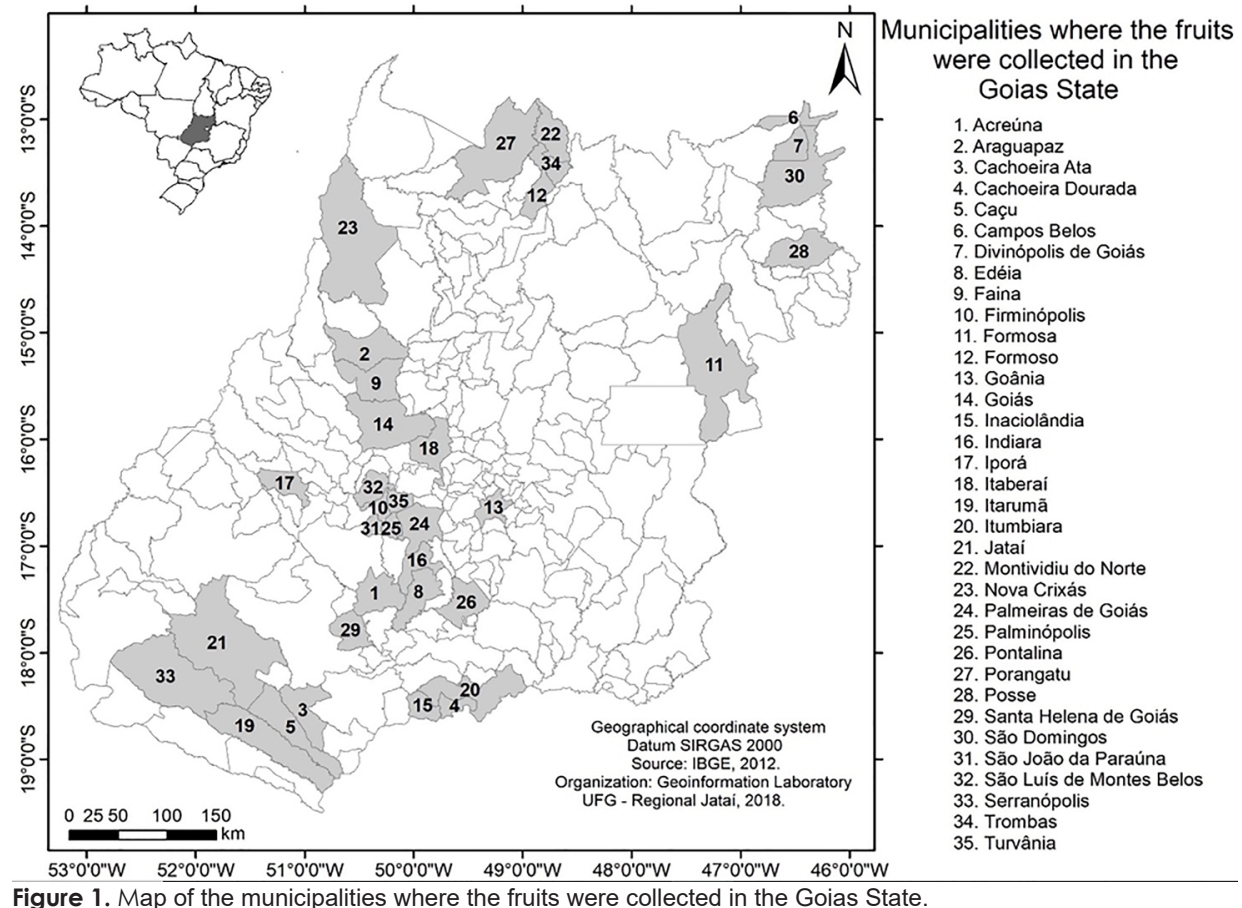

The clusters were harvested using the pericarp's subjective color criteria, when the pericarp presented $50 \%$ of the fruits at the mature maturity stage, that is, totally yellow fruits with no whitish scores (Amaral et al., 2011).

After harvesting the clusters, all fruits were separated and stored in $50 \mathrm{~kg}$ polypropylene bags, identified and packed in cardboard boxes to avoid dehydration during transportation. The boxes were transported at room temperature. 
From each accessions, ten fruits were selected for the absence of mechanical injuries. The fruits were evaluated for the following characteristics: fruit length (FL) and almond length (AL) using a digital caliper (MPD-200 with resolution of $0.01 \mathrm{~mm}, 200 \mathrm{~mm} / 8$ "band, Instrutherm, Brazil) and the results were expressed in millimeters ( $\mathrm{mm}$ ). The fruit fresh mass (FM) and the average mass of the dehydrated almond (MA) were obtained through a precision scale (Model Mh-502 Digital 0.1g / 500g) and the results expressed in grams (g). The mean number of almonds (NMA) was performed by direct counting.

It was also evaluated the oil percentage in the dehydrated almond (\% OA), being the extraction carried out in a complete soxhlet system (composed of three main sections: a percolator (a distillation flask and a reflux condenser), which allows the reflux of the solvent; a thimble (a filter, usually consisting of thick filter paper), which retains the solid particles; and a siphon, which empties periodically the chamber where the thimble is placed), according to Amaral et al. (2011). The oil percentage of the dehydrated fruit (\% OF), after the oil extraction the total oil percentage in the fruit was calculated.

For the descriptive statistical analysis, measures of central tendency (average) and data variability (standard deviation and coefficient of variation) were used and the Person's correlation was estimated between all evaluated characteristics.

The relative importance of each trait studied for genetic divergence among the 137 accessions was obtained by the method of singh (1981). The descriptive statistical analysis, Person correlation and the relative importance of the characteristics by the Singh method were performed with the aid of the Genes software (Cruz, 2013).

Then genetic divergence was evaluated among the 137 materials and classified in similarity groups applying the multivariate technique, using Ward's agglomerative hierarchical clustering method (Ward, 1963). For a better visualization of the agglomerative process, a dendrogram was generated with the values of the semipartial squared statistic correlation. This statistical analysis corresponds to the proportion of the sum of squares between the groups that was grouped to form each new group, in relation to the total sum of the average squares (SantosGarcia et al., 2012).

For the definition of the best number of groups to be adopted, the Pseudo $T^{2}$ statistic (PST ${ }^{2}$ ) (Duda \& Hart, 1973) was used. After the definition of the number of groups, variance (univariate) analysis was performed to evaluate the effects of the groups on each variable.

Later, the genetic divergence was evaluated between the groups defined by the Pseudo $T^{2}$ (PST $^{2}$ ) statistic (Duda \& Hart, 1973), generating a Ward dendrogram (Ward, 1963). Then, the comparisons between the means of the groups were performed, for each variable, using the Tukey's test, at a $5 \%$ of probability. The purpose of this analysis was to facilitate the interpretation and evaluation of the different groups regarding to the morphological characteristics. All multivariate analysis were performed using the SAS (SAS University Edition) software.

\section{Results and discussion}

It was observed the occurrence of a wide variation between the coefficients of variation (CV) of each studied characteristic (Table 1). These results demonstrated that the studied material presents morphological variability, and the CV obtained for fruit length $(F L)$, fruit diameter (FD) and fresh fruit mass (FM) were higher than those reported by Brandão et al. (2014) and Nobre et al. (2015), evidencing higher amplitude of the values obtained for $\mathrm{FL}$, FD and FM, which ranged from 30.5 to 49.3; 29.7 to 73.7 and 7.84 to 40.49 , respectively. However, the oil percentage in the dehydrated almond (\%OA) presented amplitude ranging from $25.82 \%$ to $71.76 \%$, which is a larger amplitude when compared to the result obtained by Amaral et al. (2011), evidenced high genetic diversity among harvesting points.

The characteristics that contributed least to the increase in variability were almond mass (AM) and number of almonds (NMA). In contrast, the variables that contributed the most to the variability were fresh fruit mass (DM), fruit diameter 
(DF) and percentage of oil in the almond (\% OA), which presented, respectively, 19.91\%, $26.89 \%$ and $27.42 \%$ of contribution to the morphological variation.

These results demonstrate that the state of Goiás has a greater morphological variability of the fruit when compared to the study of characterization of macaw palm fruits in the state of Minas Gerais State published by Brandão et al., 2014; Nobre et al., 2015 and of São Paulo State (Amaral et al., 2011). Fruits from the 137 municipalities of the present study stood for the weight and percentage of oil in the almond.

Table 1. Means of nine evaluated characteristics in fruits of 137 accessions from macaw palm at Goias, Brazil.

\begin{tabular}{cccccccc}
\hline Variable & Mean & Minimum & Maximum & C.V & Variance & SD & S.j \\
\hline FL (mm) & 37.82 & 30.5 & 49.3 & 10.76 & 16.59 & 4.07 & 10.63 \\
AL (mm) & 10.36 & 2.90 & 20.95 & 27.22 & 7.95 & 2.82 & 5.09 \\
FD (mm) & 37.69 & 29.7 & 73.7 & 17.18 & 41.97 & 6.47 & 26.89 \\
AD (mm) & 13.71 & 5.90 & 31.51 & 26.70 & 13.41 & 3.66 & 8.59 \\
FM (g) & 1.51 & 7.84 & 40.49 & 36.81 & 31.07 & 5.57 & 19.91 \\
MA (g) & 1.02 & 0.37 & 2.14 & 36.06 & 0.13 & 0.37 & 0.09 \\
NMA & 1.33 & 1 & 2.40 & 27.56 & 0.13 & 0.36 & 0.09 \\
\%OA & 49.76 & 25.82 & 71.76 & 13.14 & 42.79 & 6.54 & 27.42 \\
\%OF & 3.90 & 0.45 & 8.13 & 36.07 & 1.98 & 1.40 & 1.27 \\
\hline Fruit length (FL) and almond length (AL); fruit diameter (FD); almond diameter (AD). Fruit fresh mass (FM); dehydrated \\
almond mass (PA); number of almonds (NMA) by direct counting, oil percentage on the dehydrated almond (\%OA), oil \\
percentage of the dehydrated fruit (\%OF)
\end{tabular}
percentage of the dehydrated fruit (\%OF).

According to the Pearson's correlation (Table 2) of the evaluated characteristics, it is possible to observe a positive and significant correlation between $66 \%$ of the evaluated characteristics, being the correlations ranging from $18 \%$ to $70 \%$. The fruit length was not significantly correlated to the almond length and almond oil percentage. On the other hand, the oil percentage was not significantly correlated to fruit diameter, and the correlations varied from $18 \%$ to $61 \%$, indicating that the selection of these variables can be important for future breeding

Table 2. Correlations among nine evaluated fruit characteristics of 137 macaw palm accessions from the Goias State.

\begin{tabular}{|c|c|c|c|c|c|c|c|c|}
\hline & FL (mm) & FD $(\mathrm{mm})$ & PF (g) & $\mathrm{AL}(\mathrm{mm})$ & $\mathrm{DA}(\mathrm{mm})$ & PA (g) & NMA & $\% O A$ \\
\hline $\mathrm{FD}(\mathrm{mm})$ & $0.54^{* *}$ & & & & & & & \\
\hline FM (g) & $0.70^{* *}$ & $0.46^{* *}$ & & & & & & \\
\hline $\mathrm{AL}(\mathrm{mm})$ & 0.10 & 0.10 & 0.11 & & & & & \\
\hline$A D(\mathrm{~mm})$ & $0.26^{* *}$ & $0.21^{*}$ & $0.39^{* *}$ & $0.53^{* *}$ & & & & \\
\hline$M A(g)$ & $0.38^{* *}$ & $0.30 * *$ & $0.43^{* *}$ & $0.44^{* *}$ & $0.36^{* *}$ & & & \\
\hline NMA & $0.41^{* *}$ & $0.19^{* *}$ & $0.54^{* *}$ & $-0.15^{* *}$ & $0.23^{* *}$ & -0.03 & & \\
\hline \%०A & 0.08 & 0.06 & 0.05 & 0.01 & -0.01 & 0.12 & 0.10 & \\
\hline \%OF & $0.18^{*}$ & 0.13 & $0.26^{* *}$ & $0.27^{* *}$ & $0.37^{* *}$ & $0.61^{* *}$ & $0.33^{* *}$ & $0.32^{* *}$ \\
\hline
\end{tabular}

The cluster analysis by the Ward's method, along with the criterion for defining the number of Pseudo T2 groups, indicates the formation of six groups. It can be noticed in the dendrogram (Figure 2) the partitioning of accessions in six groups, which varied from 15 to 35 accessions per group, with the largest studies.

According to Pinto et al. (2010), the study of correlations between morphological descriptors of agronomic importance can be useful to select materials. The determination of the relations of the production components with other descriptors is important since it can direct strategies to be adopted in a breeding program and, in the case of perennial plants, such as macaw palm, allows the anticipation of the results. 


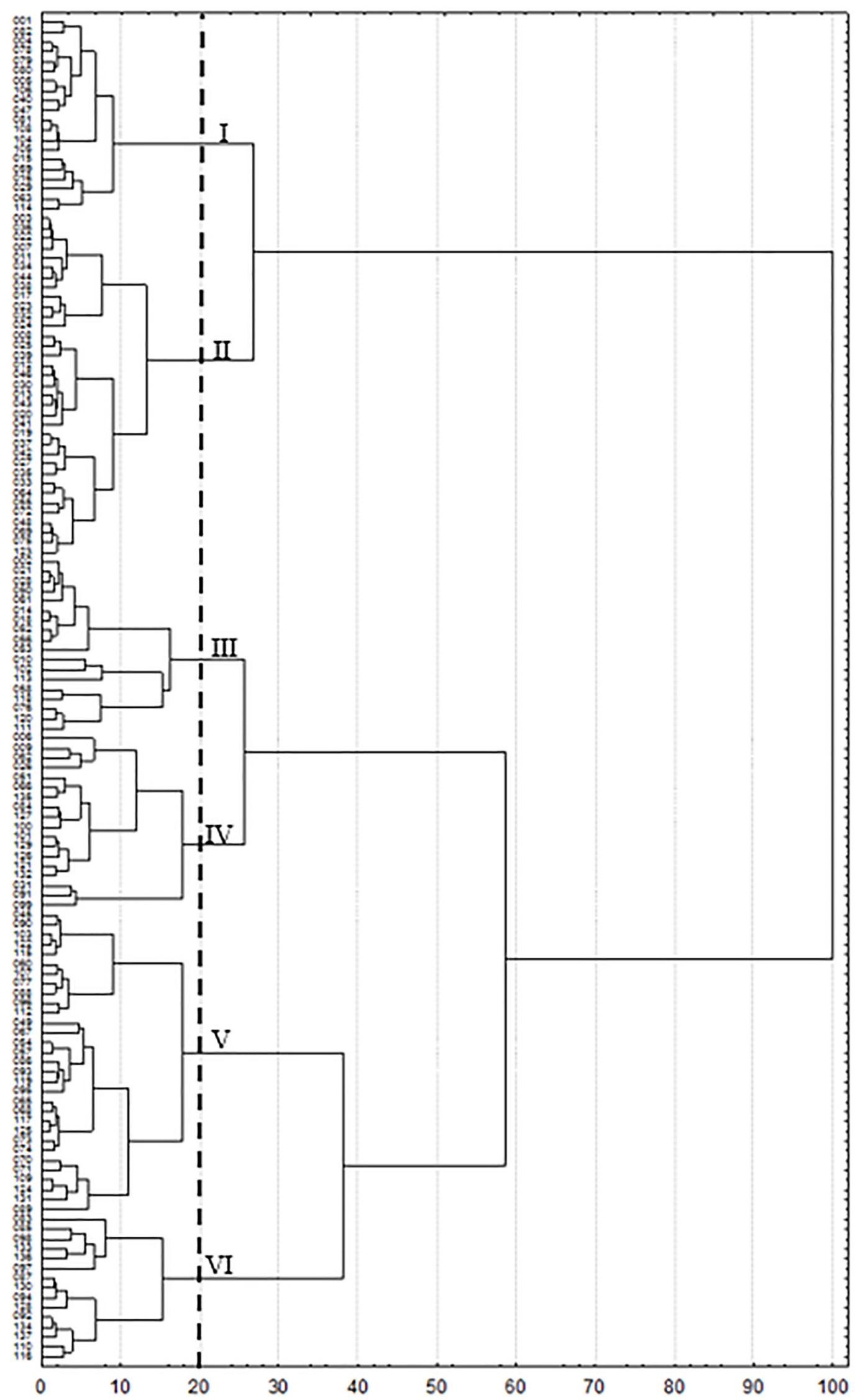

Figure 2. Dendrogram of 137 macaw palm accessions from the State of Goiás, using the Ward's method, using nine morphological characteristics, in relation to the semi partial correlation to the square (SPRSQ). The dotted vertical line represents the stopping point of the algorithm for the formation of the six access groups. 
The groups were mostly constituted by accessions from geographically close municipalities, but presenting some accessions from geographically distant municipalities (Table 3). This result reinforces the consistency of the results obtained by Manfio et al., (2012), which reports a certain tendency of grouping macaw palm accessions according to their geographical origin, which is also observed by Reis et al (2017).

Table 3 - Distribution of 137 macaw palm accessions from the state of Goiás according to the groups formed by the Ward's method.

\begin{tabular}{|c|c|}
\hline Groups & Municipalities \\
\hline I & $\begin{array}{c}\text { Acreúna, Araguapaz, Divinópolis de Goiás, Faina, Firminópolis, Formosa, Goiás, Itaberaí, Montividiu } \\
\text { do Norte, Nova Crixás, São Domingos, Turvânia }\end{array}$ \\
\hline II & $\begin{array}{l}\text { Araguapaz, Cachoeira Dourada, Campos Belos, Divinópolis de Goiás, Faina } \\
\text { Goiás, Itaberai, Montividiu do Norte, Nova Crixás, Pocelândia, Porangatu, São Domingos, Formoso }\end{array}$ \\
\hline III & $\begin{array}{c}\text { Edéia, Faina, Formosa, Goiás, Indiara, Itaberaí, Itumbiara, Paranã, Montividiu do Norte, Nova } \\
\text { Crixás, Palmeiras de Goiás, Palminópolis, Porangatu, Formoso }\end{array}$ \\
\hline IV & $\begin{array}{c}\text { Acreúna, Caçu, Campos Belos, Acreúna, Cachoeira Alta, Cachoeira Dourada, Caçu, Campos } \\
\text { Belos, Divinópolis de Goiás, Edéia, Faina, Firminópolis, Iporá, Itaberaí, Itarumã, Pocelândia, } \\
\text { Porangatu, Santa Helena, São Luis de Montes Belos, Serranópolis }\end{array}$ \\
\hline$\vee$ & $\begin{array}{l}\text { Acreúna, Cachoeira Dourada, Edéia, Faina, Firminópolis, Goiânia, Goiás, Inaciolândia, Indiara, } \\
\text { Iporá, Itarumã, Itumbiara, Pocelândia, Pontalina, São João da Paraúna, São Luis de Montes Belos }\end{array}$ \\
\hline $\mathrm{VI}$ & $\begin{array}{c}\text { Turvânia, Caçu, Edéia, Firminópolis, Indiara, Iporá, Itarumã, Jataí, São João da Paraúna, São Luis } \\
\text { de Montes Belos, Serranópolis }\end{array}$ \\
\hline
\end{tabular}

It is possible to observe in Table 4 that the smaller distances were evidenced within the groups, it is also verified that the larger intragroup distances involved groups I and $\mathrm{VI}$, indicating that these groups are more divergent when compared to other groups. Intergroup distances varied from 0.266 to 0.891 , with the most similar groups being II and III (0.266), and the most divergent were I and $\mathrm{VI}(0.891)$ (Figure 3). These results confirm the efficiency in the access partitioning in six groups, with the minimum of intragroup divergence and the maximum of intergroup divergence. This allows the detection of heterosis and enables the identification of promising accessions (Sudré et al., 2005). It was possible to observe that the level of heterosis is directly related to the genetic distance observed among parents.

The use of the genetic distance of parents, based on a satisfactory set of traits, promises to identify advantageous combinations that can contribute to the selection of parents to be crossbred, aiming a greater segregation and success in a breeding program (Miranda et al. 1988), since the interbreeding of individuals belonging to the groups is not indicated when the interest is the search for heterotic effect.

Table 4. Means of intra and intergroups of the distance of six groups formed by the ward's method for the 137 macaw palm accessions from the Goias State.

\begin{tabular}{ccccccc}
\hline Groups & I & II & III & IV & V & VI \\
\cline { 2 - 7 } I & $0.148(20)$ & & & & & \\
II & 0.466 & $0.17(35)$ & & & & \\
III & 0.695 & 0.266 & $0.257(18)$ & & & \\
IV & 0.656 & 0.359 & 0.364 & $0.221(18)$ & & \\
V & 0.531 & 0.369 & 0.424 & 0.405 & $0.166(31)$ & \\
VI & 0.891 & 0.685 & 0.596 & 0.442 & 0.501 & $0.208(15)$ \\
\hline
\end{tabular}

The univariate analysis of variance (Table 5) for the six groups indicate a significance of groups at $1 \%$ of probability for all evaluated characteristics. This result, according to SantosGarcia et al. (2012) is an indication that grouping analysis was able to discriminate accessions in dissimilarity groups, which affirm their divergences, even when the variables are analyzed independently. 


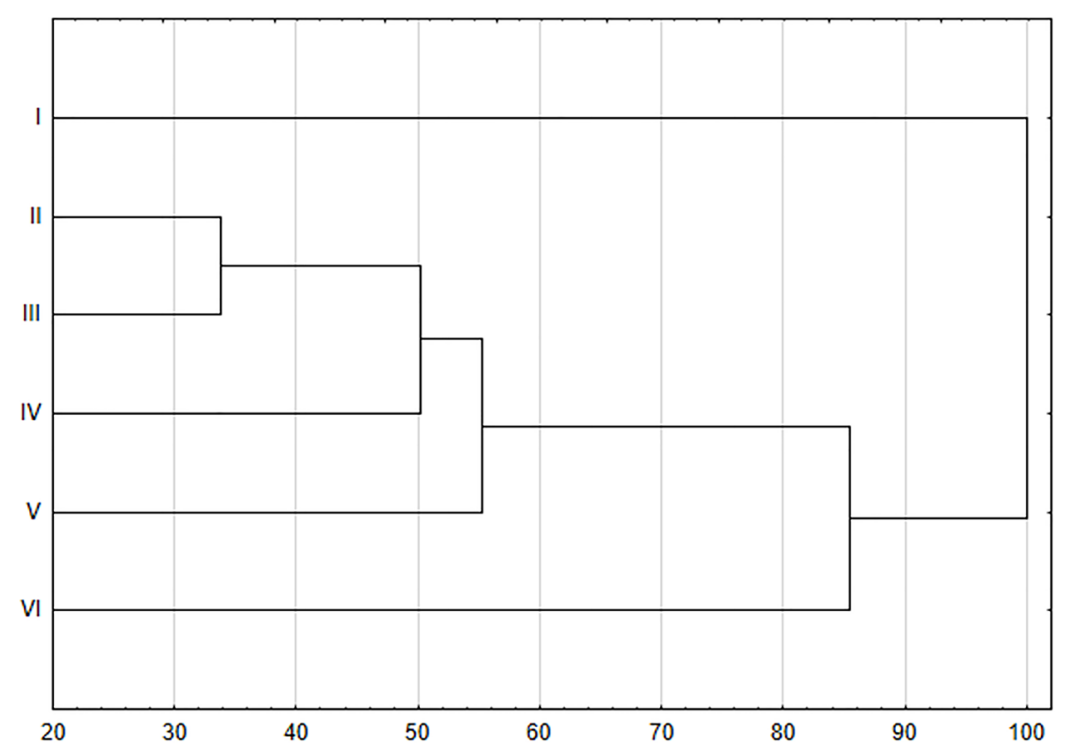

Figure 3. Dendrogram of the grouping of the six groups of macaw palm from Goiás, Brazil, using the Ward's method and nine morphological characteristics.

Table 5. Univariate analysis of variance and comparison of means of similarity groups, formed from cluster analysis.

\begin{tabular}{|c|c|c|c|c|c|c|c|c|c|}
\hline \multirow{2}{*}{ Variables } & \multicolumn{3}{|c|}{ Anova } & \multicolumn{6}{|c|}{ Groups means ${ }^{1}$} \\
\hline & MS & CV (\%) & Mean & I & II & III & IV & V & VI \\
\hline $\mathrm{FL}(\mathrm{mm})$ & $419.25^{* *}$ & 7.31 & 38.47 & $35.91 d$ & $35.68 d$ & $36.39 \mathrm{~cd}$ & $40.48 b$ & $37.84 \mathrm{C}$ & $44.54 a$ \\
\hline $\mathrm{FD}(\mathrm{mm})$ & $372.27^{* *}$ & 13.08 & 37.79 & $34.17 \mathrm{~b}$ & $36.03 b$ & $35.61 b$ & $42.19 a$ & 37.37b & $41.36 a$ \\
\hline$P F(g)$ & $955.34^{* *}$ & 21.44 & 16.40 & $12.01 \mathrm{c}$ & $11.87 c$ & $15.01 b$ & $17.31 b$ & $16.11 \mathrm{~b}$ & $26.09 a$ \\
\hline $\mathrm{AL}(\mathrm{mm})$ & $101.17^{* *}$ & 20.41 & 10.13 & $7.60 c$ & $11.14 a b$ & $11.88 a$ & $11.31 \mathrm{ab}$ & $8.546 c$ & $10.33 b$ \\
\hline $\mathrm{DA}(\mathrm{mm})$ & $158.64^{* *}$ & 20.13 & 13.91 & $10.68 d$ & $12.74 \mathrm{C}$ & $15.15 a b$ & $14.33 \mathrm{bc}$ & $13.61 \mathrm{bc}$ & $16.92 a$ \\
\hline PA (g) & $2.39 * *$ & 24.67 & 1.02 & $0.60 \mathrm{e}$ & $0.99 \mathrm{~cd}$ & $1.314 a$ & $1.13 \mathrm{bc}$ & $0.86 d$ & $1.23 a b$ \\
\hline NMA & $4.04^{* *}$ & 14.87 & 1.364 & $1.140 c$ & $1.09 c$ & $1.16 \mathrm{c}$ & $1.21 \mathrm{C}$ & $1.69 \mathrm{~b}$ & $1.89 a$ \\
\hline$\% O A$ & $283.35^{* *}$ & 11.08 & 49.64 & $44.40 \mathrm{~b}$ & $50.02 a$ & $52.46 a$ & $49.97 a$ & $51.78 a$ & $49.21 a$ \\
\hline$\% O F$ & $26.95^{* *}$ & 27.27 & 3.83 & $2.26 c$ & $3.71 \mathrm{~b}$ & $4.45 a$ & $3.69 \mathrm{~b}$ & $4.11 \mathrm{ab}$ & $4.78 a$ \\
\hline
\end{tabular}

It can be evidenced that the group $\mathrm{VI}$ stood out for all the evaluated characteristics and that the group III presented highest averages for almond mass, almond oil percentage and oil percentage in the dried fruit. In general, group IV presented intermediate means between groups $\checkmark$ and III. On the other hand, group I presented lower averages for all evaluated characteristics. These results provide subsidies for the selection of accessions that should be part of the group of parents in future breeding studies aimed to increase heterosis in macaw palm, with emphasis on fruit size and percentage of oil in the almond.

\section{Conclusions}

It was observed a wide phenotypic variability among the macaw palm accessions from the state of Goiás. The characteristics that contributed most to the variability were fruit mass and diameter and almond oil percentage.

Six similarity groups were established with significant effect for all evaluated characteristics.

The group VI presented accessions with higher almond mass, almond and dry fruit oil percentage.

\section{Acknowledgments}

To the National Council for Scientific and Technological Development (CNPq), to the Coordination for the Improvement of Higher Education Personnel (CAPES) and the Foundation for Research Support of the State of Goiás, for the financial support

\section{References}

Amaral, F. P., Broetto, F., Batistela, C. B., Jorge, S. M. A. 2011. Extraction and qualitative characterization of pulp and almonds oils of 
macauba fruits [Acrocomia aculeata (Jacq) Lodd. ex Mart] collected in the region of Botucatu, SP. Energia na Agricultura 26: 1-20.

Bertan, I., Carvalho, F.I.F. de, Oliveira, A.C. de, Vieira, E.A., Hartwig, I., Silva, J.A.G. da, Shimidt, D.A.M., Valério, I.P., Busato, C.C., Ribeiro, G. 2006. Comparação de métodos de agrupamento na representação da distância morfológica entre genótipos de trigo. Revista Brasileira de Agrociência 12: 279-286.

Brandão, A.A., Neves, J.M.G, Silva, H.P., Continho, P.H., Aquino, C.F., Santos, P.A., Brandão, D.S. 2014. Caracterização biométrica de frutos de macaw palm em diferentes estádios de maturação, provenientes de duas regiões do estado de Minas Gerais. Global Science and technology 7: 15-23.

Coimbra, M. C., Jorge, N. 2011 . Characterization of the pulp and kernel oils from Syagrusoleracea, Syagrusromanzoffiana, and Acrocomia aculeata. Journal of Food Science 76: 1151-1161.

Chagas, K; Alexandre, R. S. ; Schmildt, E. R. ; Bruckner, C. H. ; Faleiro, F. G.2016. Genetic diversity in genotypes of the sour passion fruit, based on the physical and chemical characteristics of the fruit. Revista Ciência Agronômica 47: 524-531.

Cruz, C.D. 2013. GENES - a software package for analysis in experimental statistics and quantitative genetics. Acta Scientiarum 35: 271-276.

Domiciano, G. P., Alves, A. A., Laviola, B. G., Conceição, L. D. H. C. S. da. 2015. Parâmetros genéticos e diversidade em progênies de Macaw palm com base em características morfológicas e fisiológicas. Ciência rural 45: 1599-1605.

Duda, R. O., Hart, P. E. 1973. Pattern Classification and Scene Analysis. New York, USA, 419 p.

Farias Neto, J. T. de, Clement, C. R.; Resende, M. D. V. de. 2013. Estimativas de parâmetros genéticos e ganho de seleção para produção de frutos em progênies de polinização aberta de pupunheira no Estado do Pará, Brasil. Bragantia 72: 122-126.

Manfio, C. E., Motoike, S. Y., Resende, M. D. V. de, Santos, C. E. M. dos, Sato, A. Y. 2012. Avaliação de progênies de macaw palm na fase juvenil e estimativas de parâmetros genéticos e diversidade genética. Pesquisa Florestal Brasileira 32: 63-69.

Matsimbe, S. F. S.; Motoike, S. Y.; Pinto, F. A. de C.; Leite, H. G. e Marcatti, G. E. 2015. Prediction of oil content in the mesocarp of fruit from the macauba palm using spectrometry. Revista Ciência Agronômica 46: 21-28.
1988. Predição do comportamento de híbridos de pimentão (Capsicum annuum L.) pela divergência genética dos progenitores. Revista Brasileira de Genética 11: 929-937.

Nobre, D.A.C.; David, A.M.S, Maia, V.M.; Resende, J.C.F.; Nobre, E.C. 2015. Caracterização morfometria de uma população natural de macaw palm no Norte de Minas Gerais. Energia na Agricultura 30: 290-293.

Pimentel, L. D., Bruckner, C. H., Martinez, H. E. P., Motoike, S. Y., Manfio, C. E. e Santos, R. C. dos. 2015. Effect of nitrogen and potassium rates on early development of macaw palm. Revista Brasileira de Ciência do Solo 39: 1671-1680.

Pinto, J. F. N., Reis, E. F., Faleiro, F. G., Barbosa, E. C. C., Nunes, H. F., Pinto, J. F. N. 2010. Seleção de descritores vegetativos para caracterização de acessos de guariroba (Syagrus oleracea (Mart.) Becc.). Revista Brasileira de Fruticultura 32: 832839.

Oliveira, D., Medeiros, M., Pereira, S., Oliveira, M. G. F., Arruda, E., Santos, M. 2016 . Ecophysiological leaf traits of native and exotic palm tree species under semi-arid conditions. Bragantia 75: 128-134.

Reis, E.F.; Pinto, J.F.N.; Assunção, H.F.; Silva, D.F.P. 2017; Genetic diversity of Macaw palm fruits from 35 municipalities of the state of Goiás, Brazil. Pesquisa Agropecuária Brasileira 52: 277-282.

Santos-Garcia, M. O., Toledo-Silva, G. de, Sassaki, R. P., Ferreira, T. H., Resende, R. M. S., Chiari, L., Karia, C. T., Carvalho, M. A., Faleiro, F. G., Zucchi, M. I., Souza, A. P. de. 2012. Using genetic diversity information to establish core collections of Stylosanthes capitata and Stylosanthes macrocephala. Genetics and Molecular Biology 35: 847-861.

Silva, D. F. P., Matias, R. G. P., Silva, J. O. da C. e ; Salazar, A. H. ; Bruckner, C. H. 2016. Characterization of white-fleshed peach cultivars grown in the Zona da Mata area of Minas Gerais State, Brazil. Comunicata Scientiae 7: 149-153.

Singh, D. 1981. The relative importance of characters affecting genetic divergence. The Indian Journal of Genetic and Plant Breeding 41: 237-245.

Sudré, C.P., Rodrigues, R., Riva, E.M., Karasawa, M., Amaral-Júnior, A.T. 2005. Divergência genética entre acessos de pimenta e pimentão utilizando técnicas multivariadas. Horticultura Brasileira 23: 22-27.

WARD, J. H. Hierarchical grouping of otimize an objetive function. Journal American Statistical Association 58: 236-244.

Miranda, J.E.C. de; Cruz, C.D.; Costa, C.P. da. 